\title{
Performance of land reform projects in the North West Province of South Africa: Changes over time and possible causes
}

\author{
Johann Kirsten ${ }^{\mathrm{a}^{*}}$, Charles Machethe $^{\mathrm{b}}$, Talent Ndlovu $^{\mathrm{c}}$ \& Pascalina Lubambo ${ }^{\mathrm{d}}$ \\ ${ }^{a}$ Head of Department, Agricultural Economics, Extension and Rural Development, University of Pretoria, Pretoria, South \\ Africa \\ ${ }^{b}$ Director, Post-Graduate School of Agricultural Economics, Extension and Rural Development, University of Pretoria, \\ Pretoria, South Africa \\ 'Master's student, Agricultural Economics, Extension and Rural Development, University of Pretoria, Hatfield, South Africa \\ ${ }^{\mathrm{d}}$ Master's student, Agricultural Economics, Extension and Rural Development, University of Pretoria, Hatfield, South Africa
}

\section{ABSTRACT}

Anecdotal evidence as well as selected studies on the performance and progress of South Africa's land reform programme generally present mixed to rather negative results. Few longitudinal studies exist on the progress of redistributed farms, resulting in an incomplete picture of the performance and progress of land reform projects. In this paper, we report on the progress and performance of a group of land reform projects in the North West Province of South Africa over five years. As part of a comprehensive audit of land reform projects in the North West Province, 43 farms were studied in 2005 to assess their performance, based on their production status. Five years later, in 2010, 37 of these farms were visited again to review their progress. The results indicate that the production status (and thus performance) of land reform projects is not static. Although some projects either improved or maintained their initial production status, the overall trend shows deterioration in performance. Numerous factors are responsible for the decline, including group characteristics where farms are owned by groups of beneficiaries. The paper is thus the first to use two surveys of a group of land reform projects to show the true status of farms in their post-transfer phase in South Africa.

\section{Introduction}

To redress the imbalances in land ownership, the South African government introduced a comprehensive land reform programme in 1994. Implicit in the vision of the land reform programme is that (a) farms transferred to new land owners should be commercially viable; and (b) previously disadvantaged farmers should be assisted to achieve commercial viability. However, the reality is that many land reform projects have failed to achieve commercial viability.

Although anecdotal evidence of failed land reform projects is abound and widely reported in the media in South Africa, empirical studies that systematically evaluate the status of these farms/land reform projects are limited. The few studies that we know of are only once-off in nature, with no follow-up visits (e.g. Bradstock, 2005; AgriAfrica, 2005; Lahiff \& Cousins, 2005). Consequently, the results of these studies are biased due to the once-off nature of the investigations. 
In this paper, we report on the progress of a group of land reform projects in the North West Province of South Africa studied in two periods. As part of a comprehensive audit of land reform projects in the North West Province (see Kirsten and Machethe, 2005), 43 farms were studied in detail to assess their production status and economic performance. Five years later, in 2010, 37 of these farms were revisited to review their progress (see Lubambo, 2012).

The two datasets of the 37 farms that were included in the 2005 and 2010 surveys provide a unique opportunity to reflect on the agricultural performance of the redistributed farms five years apart. What is demonstrated in this paper is that the status and performance of land reform projects do change over time, with some farms deteriorating while others have recovered from an initial position of no production where farms are now active in production. The paper challenges the stereotyped views about the performance of land reform projects in South Africa shaped by media reports and sceptics amongst commercial farmers. The results from our analysis do however confirm some of the anecdotal evidence and international experience with land reform projects. The paper is thus the first to use two surveys of a group of land reform projects to show the true status of farms in their post-transfer phase. This paper is therefore different to the studies undertaken by Agri Africa (2005) for the Western Cape and the national study of 1002 LRAD projects by the Public Service Commission in 2011 (see Public Service Commission, 2011). Despite the fact that this paper is presented five years since the second survey in 2010, we are still able to highlight important and useful changes in the performance of redistributed farms that could provide additional insight for improved design of the mechanisms and support systems for land reform.

The paper is organised as follows. We first provide some context by reviewing the main aspects of the South African land reform programme and how the programme has evolved in terms of its composition and implementation since 1994. Since the programme has as an important objective the sustainable and productive use of land, section 3 of the paper considers the criteria for reviewing the progress of land reform projects. These criteria are then used as a basis for reviewing the progress of selected land reform projects in the North West Province of South Africa. The methods and procedures, including the selection of the projects are presented in section 4 . Section 5 outlines the main characteristics of the selected projects. The progress of the 37 projects since the first visit in 2005 is reviewed in section 6. The factors influencing the progress of the projects are identified in section 7. Over the years, media articles and experiences by implementing agents and mentors contributed to the anecdotal evidence about the success of land reform projects that were never tested empirically. Section 8 , therefore, tests these views or propositions by analysing the data from the different projects. With all of these analyses in mind, combined with additional results from the two rounds of surveys, we conclude with a discussion of the major challenges facing land reform projects and land reform beneficiaries that require urgent policy attention.

\section{South Africa's land reform programme in context}

Three sub-programmes, land restitution, land redistribution and tenure reform guide the land reform process. The purpose of land restitution is to compensate victims who were dispossessed of their land rights during the apartheid era after the enactment of the 1913 Land Act. Tenure reform, on the other hand, aims to devise and strengthen secure forms of land tenure by "bringing all people occupying land under a legally secure system of landholding" (DLA, 1997:7). The targeted beneficiaries of this policy are people living in the former homelands and rural areas, where weak 
tenure forms are prevalent. The focus of land redistribution is to enable equitable access to land, thus easing congestion in communal areas and diversifying the ownership structure of commercial farmland. The objective was to transfer $30 \%$ of commercial farmland to black farmers by 2015 . The redistribution of vast tracks of productive agricultural land makes land redistribution potentially the most important component of land reform (Lahiff, 2008).

South Africa has implemented land redistribution in two distinct phases. The initial phase (1995 to 1999) only catered for previously disadvantaged (racially discriminated) poor households who earned not more than R1500 per month. Applicants could also access grants through the Settlement and Land Acquisition Grant (SLAG) scheme and purchase land, usually in groups on the open market.

The second phase involved the implementation of the Land Reform for Agricultural Development (LRAD) programme and emphasised commercial agricultural land use. The income ceiling was removed to accommodate a wider spectrum of historically disadvantaged beneficiaries. To qualify for LRAD, applicants had to be previously disadvantaged, be serious about farming and making farming a success. Individuals rather than households, as in the case of SLAG, could access the larger LRAD grants. This allowed families to pull their resources together and buy family farms (HSRC, 2003; Lahiff, 2007). It is important to highlight here that the objectives of LRAD were quite specific and more direct than the White Paper of 1997. The objectives that implicitly suggest that the farms should be commercially viable for the programme to be successful are ${ }^{1}$ :

- Improve nutrition and incomes of the rural poor who want to farm on any scale;

- Facilitate structural change over the long term by assisting black people who want to establish small and medium-sized farms;

- Stimulate growth from agriculture;

- Create stronger linkages between farm and off-farm income-generating activities;

- Expand opportunities for promising young people who stay in rural areas;

- Empower beneficiaries to improve their economic and social well-being;

- Enable those presently accessing agricultural land in communal areas to make better productive use of their land; and

- Promote environmental sustainability of land and other natural resources.

Our initial survey also interrogated the objectives of land acquisition as expressed by the beneficiaries themselves. Although the acquisition of farms was in most cases motivated by the opportunity land ownership would provide for commercial farming, the acquisition of farmland is certainly also seen by many as a means to alleviate poverty and create employment. Improvement of quality of life is also viewed as an objective for acquiring a farm. The improvement of quality of life on a farm would be achieved through employment or farming; it could however also be achieved through improved services (the acquisition of land to ensure the future of a farm school) and the residential security title to land would provide. Although the improvement of quality of life as an objective for land acquisition is largely intertwined with farming and poverty alleviation, the distinction between poverty alleviation, quality of life and commercial farming is, however, also not entirely superficial. In fact, although the objectives for acquiring farms cannot be neatly

\footnotetext{
${ }^{1}$ We have therefore decided in this paper to evaluate the land reform projects on their agricultural performance to determine whether these objectives could be met.
} 
distinguished, many beneficiaries of land reform associate the acquisition of land rather with poverty alleviation and quality of life or livelihood issues than with commercial farming.

Evidence from numerous studies indicates that the land redistribution sub-programme has not been successful in meeting the objectives listed earlier or the objectives expressed by the beneficiaries. Firstly, the speed of land redistribution is slower than intended. Secondly, land reform projects are failing to deliver on the promises of sustainable agricultural production for the generation of income, employment, food security, poverty alleviation and rural development (Hall, 2003; Bradstock, 2005; Kirsten and Machethe, 2005; Lahiff et al., 2012). However, it is difficult to track the progress of land reform over time and thus contribute to the larger debate on land reform issues regarding the optimal design of a land reform programme. This is because of major information gaps on all aspects of the sub-programme. These include detailed statistics on beneficiaries, the geographical spread of projects, types of land acquired, types of financing used and types of land use (Lahiff and Li, 2012; Hall, undated). This paper contributes to this on-going debate by assessing the performance of 37 land reform projects in the North West Province over a five-year period. The broader objective of the paper is to identify possible problems and/or limitations experienced by land reform beneficiaries and suggest possible remedies.

\section{What makes land reform successful? An international perspective}

The critical indicators or concepts used in our evaluation are 'performance' and 'success'. It is therefore important to contextualise this terminology in the international literature. The performance of land reform programmes in different countries varies, thus prompting policy makers and researchers to examine why some programmes are more successful than others.

Rozelle and Swinnen (2004) tracked the growth in agricultural output and efficiency in production in 28 countries, with various land reform packages. They found that, in the early years of reform, the creation of good rights and improved marketing environment had a positive impact on the agricultural performance of resettled farmers. Although numerous studies have also linked security of tenure to higher and more long-term investments which increase agricultural productivity, Place (2009) argues that other contextual factors such as "population density, market opportunities, climatic conditions, gender" also have a significant impact on the type and level of investments. In a review on the barriers to participation of the poor in South Africa's land reform, Zimmerman (2000) also asserts that livestock production would fare much better than crop cultivation in the country's' dry and drought-prone climatic conditions.

Zimmerman (2000) presents a convincing argument that the return of land alone would not be adequate for land reform beneficiaries to engage in meaningful agricultural activity. He asserts that, in addition to land, the success of beneficiaries will depend on their access to finance to cover the upfront and out-of-pocket costs of production, access to extension services and training to improve their technical and managerial skills, and the presence of supporting infrastructure (e.g. roads, electricity, and water). Furthermore, he suggests that the resettlement farms should be located as closely as possible to the residential homes of beneficiaries.

In his synthesis of land reform in Colombia, South Africa and Brazil, Deininger (1999) points out that, without these additional support systems to correct multiple market imperfections in the rural environments, land reform is unlikely to be a success. He mentions that some of the challenges 
include the lack of input and output markets, lack of access to start-up capital, a group of beneficiaries who are not accustomed to making entrepreneurial decisions of the nature and scale required in moderate to large-scale commercial farming. Similarly, Tilley (2007:36), in a comparative analysis of six international experiences in land reform post-settlement support, points out that Australia's example in developing the land before giving it to its beneficiaries could be a "useful pointer to other policy makers wishing to encourage maximum utilisation of land". In addition, the study revealed that it is when the state rather than the private sector takes up the role of infrastructural development and post-settlement support services that land reform will produce positive benefits.

\section{Methods and procedures}

The initial phase of this study reviewed 177 land reform projects in 2005 in the North West Province. In this phase, stratified random sampling was used to select 43 of the 177 land reform projects. This was done to ensure that the sample is representative of land reform projects as well as the different farming systems in the province ${ }^{2}$. The second phase undertaken in 2010 involved revisiting 37 of the original 43 projects. The intention was to include all the projects involved in the first phase. However, six of the projects were excluded because the beneficiaries were not available for interviews.

Data were gathered from the beneficiaries of the 37 projects using a structured questionnaire. Additional data were obtained from extension and project officers through face-to-face interviews using semi-structured questionnaires. Information on the status of the projects was obtained from existing documents on the status of land reform, reports from government offices and previous studies on land reform.

The 37 projects were grouped into four categories, based on their production status as in the first phase of the study (Kirsten and Machethe, 2005). The categories are as follows:

- $\quad$ Category 1: Projects showing increased production;

- $\quad$ Category 2: Projects showing stable production;

- $\quad$ Category 3: Projects showing decreased production; and

- $\quad$ Category 4: Projects showing no production.

The above categorisation and performance ranking are similar to those in Public Sector Commission (2011) in which projects were grouped as follows:

- $\quad$ Failed projects;

- $\quad$ Projects in decline;

- $\quad$ Projects in the balance; and

- $\quad$ Successful projects.

\footnotetext{
${ }^{2}$ The projects are located in the district municipalities of Dr Kenneth Kaunde, Ngaka Modiri Molema, Bojanala Platinum and Dr Ruth Segomotsi Mompati.
} 
Categorising the projects on the basis of their production status, which is also used as an indicator of performance, is simplistic. Ideally, indicators such as production levels, income, profit, employment, etc. should have been included. However, information on these variables was either unavailable or of poor quality and, therefore, could not be used in the analysis. A lack of accurate and verifiable numerical data on production, income, and profit; lack of records; lack of knowledge among respondents; and respondents providing incomparable data, make the data on project performance opinion based. Our qualitative classification, based on the history of the previous farm owner, observations and interviews as well as the limited data that we managed to extract helped us to alleviate problems related to data quality and to appropriately categorise the different farms.

Performance of the projects was assessed by comparing the production status or category of the project in 2005 and 2010. This enabled us to determine whether the project's performance has improved, remained unchanged or deteriorated. The next step entailed finding explanations for the change in performance. In this regard, several propositions were made based on (i) information gathered from beneficiaries, extension and project officers; and (ii) results of previous studies. The propositions were subjected to statistical tests, the outcome of which enabled us to decide whether the proposition should be accepted or not.

\section{An overview of the projects}

\subsection{Type of land reform projects and farm enterprises}

The North West Province is well known for its grain and beef production but broilers and vegetables are also important. A broad indication of the typical enterprises practised on the various land reform projects is provided in Table 1 . Livestock, grain and broiler production were the dominant enterprises on the majority of farms owned by land reform beneficiaries. It is worth highlighting that no agricultural production took place on ten farms and these were used for housing or settlement. This is not in line with the vision of the land reform programme for farms transferred to beneficiaries to be commercially viable.

Table 1: Dominant enterprises on land reform projects $(n=37)$

\begin{tabular}{|l|c|}
\hline \multicolumn{1}{|c|}{ Enterprise } & Number of projects \\
\hline Cattle (mostly in combination with grain) & 13 \\
\hline Cattle/goats & 2 \\
\hline Goats & 1 \\
\hline Sheep & 2 \\
\hline Pigs & 1 \\
\hline Broiler/vegetable & 5 \\
\hline Crop production & 3 \\
\hline No production & 10 \\
\hline Total & 37 \\
\hline
\end{tabular}

Table 2 provides a breakdown of the distribution and type of land reform projects that were analysed in detail. More than $80 \%$ of the projects included for detailed study are LRAD projects and most of them are located in the two district municipalities of Dr Ruth Segomotsi Mompati and Ngaka Modiri Molema. This suggests that our sample for in-depth analysis is representative of the 
population of land reform projects since $75 \%$ of the registered projects in North West Province are indeed LRAD projects.

Table 1: Land reform projects according to type of land reform sub-programme and location ( $n=37$ )

\begin{tabular}{|l|c|c|c|}
\hline District Municipality & Number of projects & \multicolumn{2}{|c|}{ Land reform sub-programme } \\
\cline { 3 - 4 } & & SLAG & LRAD \\
\hline Bojanala (Bokone-Bothlaba) & 3 & & 3 \\
\hline Dr Ruth Segomotsi Mompati & 12 & 2 & 10 \\
\hline Ngaka Modiri Molema & 13 & & 13 \\
\hline Dr Kenneth Kaunda & 9 & 4 & 5 \\
\hline Total & $\mathbf{3 7}$ & $\mathbf{6}$ & $\mathbf{3 1}$ \\
\hline
\end{tabular}

\subsection{Acquisition of the farms}

Although the buying of farms for land reform in North West Province through the SLAG and LRAD redistribution programmes was concluded through normal market transactions by means of the willing buyer willing seller principle. Farm purchases for land reform were, in most cases, prompted by information provided by key individuals, and assisted by government officials.

In the case of $36 \%$ of the projects initially surveyed in the study, individuals heard about land reform and "organised people" or "a group" in order to purchase the farms. Farm acquisitions by "collecting a crowd" were more associated with farms in which production is more at risk. Estate agents have been involved in a small number of the farm transactions, suggesting that the normal market mechanisms to identify and acquire land were used.

The implementation of LRAD increased the awareness and accelerated the process of land reform in North West Province. From the mid-1990s to 2000, when LRAD replaced SLAG, the beneficiaries of $42 \%$ of land reform projects took the decision to buy a farm and $48 \%$ of the beneficiaries of land reform projects decided in 2001 and 2002. This suggests that, within two years after the introduction of LRAD, the awareness of and support to the land reform programme more than doubled. The most important fact is that 73\% of the farms in our sample were acquired by 2001 which is a fairly long period (more than 10 years) to enable a proper analysis of the performance of the farms.

A final important finding about the land acquisition process is that, on most $(56 \%)$ farms, the land for acquisition was identified and acquired within a 12-month period. This finding goes against the critique that the market mechanism is not working and that white farm owners are not prepared to sell their land.

\section{Production status and agricultural performance: $2005-2010$}

Figure 1 compares the production status of the 43 projects included in the 2005 sample and that of the 37 projects covered in the 2010 survey. Only 11\% (four projects) of the 37 projects had 
increased production, compared to $23 \%$ in 2005 . In the case of projects with stable production, the proportions were 33\% and 19\% (seven projects) in 2005 and 2010, respectively. The proportion of projects with decreased production increased to $42 \%$ in 2010 compared to $23 \%$ in 2005 . There was no production on $27 \%$ of the projects in 2010 compared to $21 \%$ in 2005 . Overall, it can be concluded that the production activity on the projects was better in 2005 than in 2010.

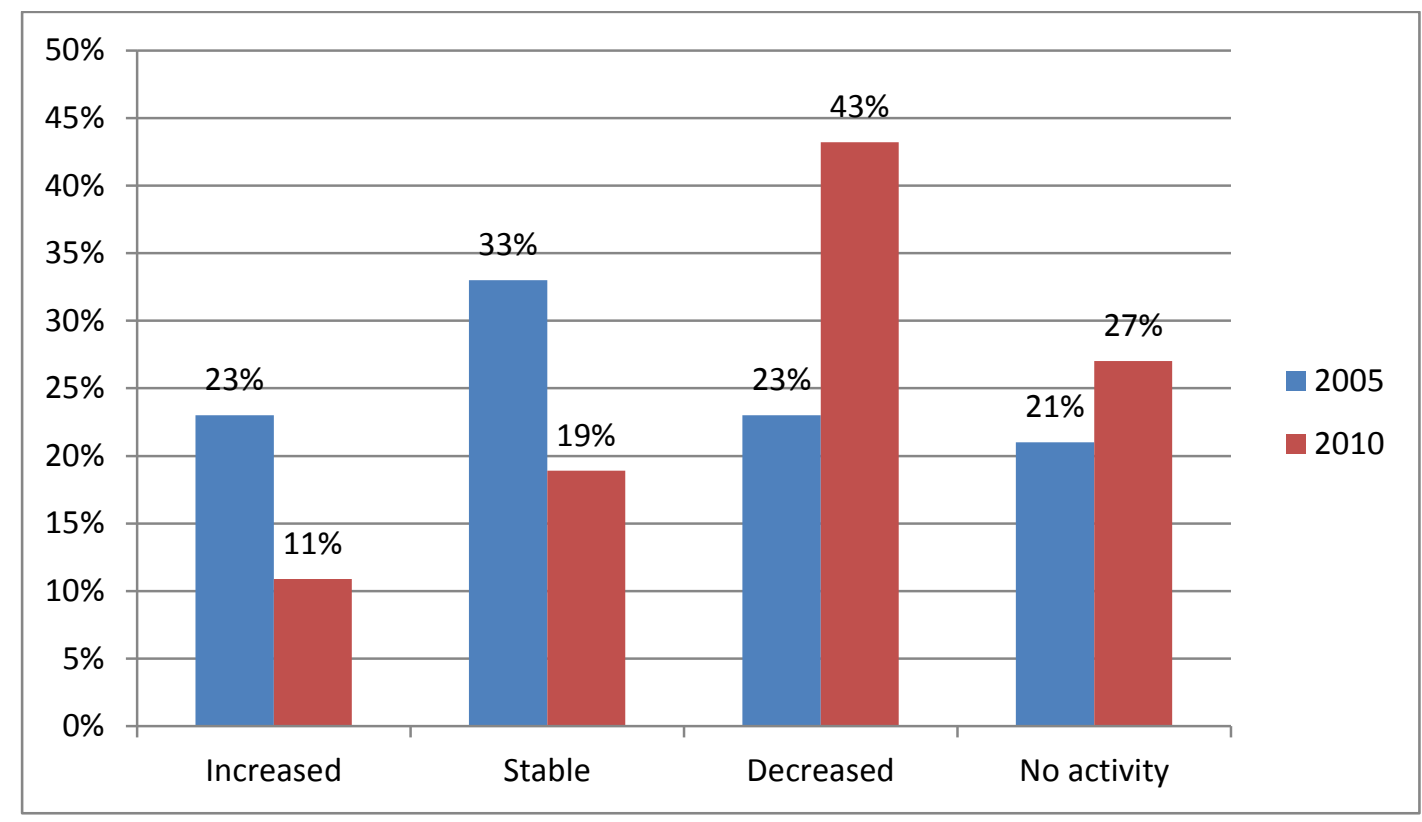

Figure 1: Production status of land reform projects: 2005 and 2010 (\% of surveyed farms) Source: Own calculations

On ten (27\%) of the visited projects in 2010 , no farming activity was observed (Figure 1). This is slightly higher than the $21 \%$ of the projects on which there was no production in 2005 . There has never been any production in three of the ten projects since the beneficiaries initially acquired the land. Six of the ten projects reported decreased production in 2005, but there was no production at all on these projects in 2010.

The category of farms showing increased production (Category 1) in 2010 included two projects that were in Category 4 (no production) and another two that were in Category 3 (decreased production) in 2005 (Table 3). None of the ten projects that were in Category 1 in 2005 were still showing increased production in 2010.

Table 3: Details of projects showing increased production (Category 1) in 2010

\begin{tabular}{|l|c|c|c|}
\hline Project & Group size & Farm size (ha) & Production status in 2005 \\
\hline 1 & 22 & 410 & Category 4 \\
\hline 2 & 8 & 20 & Category 3 \\
\hline 3 & 15 & 428 & Category 4 \\
\hline 4 & 10 & 72 & Category 3 \\
\hline Average & 18.75 & 232.5 ha & \\
\hline
\end{tabular}


The evidence presented in Table 3 also indicates that farm size and the number of beneficiaries participating in each project varies and one cannot make any reasonable prediction about the influence of these attributes on the production activity on the redistributed farms. Even more interesting is the fact that farms that could have been considered a 'total failure' in 2005 have been turned around and managed to show increasing production activity in 2010. At the same time all the farms that were considered to be performing well in 2005 (Category 1 and Category 2) have deteriorated. As indicated in Table 4, six of the ten projects that were active and growing in 2005 showed a decrease in production in 2010. The other ten projects in the 2010 list of Category 3 projects (Table 4) were also relatively successful and considered to be stable (Category 2) in 2005. Poor access to production finance, poor harvests and group conflicts were some of the reasons provided by beneficiaries for this state of affairs.

Table 4: Details of projects reporting a decrease in production (Category 3) since 2005

\begin{tabular}{|c|c|c|c|}
\hline Project & Group size & Farm size (ha) & Production status (2005) \\
\hline 1 & 127 & 856 & Category 2 \\
\hline 2 & 19 & 428 & Category 1 \\
\hline 3 & 110 & 404 & Category 2 \\
\hline 4 & 2 & 186 & Category 2 \\
\hline 5 & 6 & 201 & Category 1 \\
\hline 6 & 23 & 443 & Category 2 \\
\hline 7 & 19 & 102 & Category 2 \\
\hline 8 & 1 & 52 & Category 2 \\
\hline 9 & 2 & 7 & Category 2 \\
\hline 10 & 2 & 254 & Category 1 \\
\hline 11 & 1 & 300 & Category 1 \\
\hline 12 & 50 & 248 & Category 1 \\
\hline 13 & 6 & 255 & Category 1 \\
\hline 14 & 12 & 40 & Category 2 \\
\hline 15 & 42 & 2392 & Category 2 \\
\hline 16 & 68 & 383 & Category 2 \\
\hline Average & 30.6 & 409 ha & \\
\hline
\end{tabular}

In all the tables above, we presented important detail related to farm and group size as well as additional perspectives on the redistributed farms. We proceeded to test whether there is any significant difference in the means of farm sizes across the different production categories. There is no clear pattern as shown in Table 5 and this is confirmed by the Anova test which indicates a statistically insignificant result $(p=0.943)$.

Table 5: Summary statistics on farm size for the projects in 2010 (n=37) 


\begin{tabular}{|l|c|c|c|c|c|}
\hline & $\begin{array}{c}\text { Increased } \\
\text { production }\end{array}$ & $\begin{array}{c}\text { Stable } \\
\text { production }\end{array}$ & $\begin{array}{c}\text { Decreased } \\
\text { production }\end{array}$ & No production & TOTAL \\
\hline $\mathrm{N}$ & 4 & 7 & 16 & 10 & 37 \\
\hline Mean & 232.50 & 473.14 & 409.44 & 466.70 & 417.84 \\
\hline Std. Deviation & 216.52 & 795.53 & 567.58 & 617.47 & 586.55 \\
\hline Minimum & 20 & 21 & 7 & 9 & 7 \\
\hline Maximum & 428 & 2182 & 2392 & 1857 & 2392 \\
\hline
\end{tabular}

By comparing the performance of the projects in 2005 and 2010, it was possible to assess progress of the 37 projects that were revisited over the five-year period. As shown in Figure 2, there is a general downward trend in performance of the land reform projects. By 2010 , only $18.9 \%$ of the projects had improved their performance, $10.8 \%$ had remained the same, $62.2 \%$ had deteriorated and $8.1 \%$ had remained unproductive. The corresponding figures for 2005 were $23.3 \%, 32.6 \%$, $23.3 \%$ and $20.9 \%$. The large proportion (62.2\%) of projects that have deteriorated clearly points to a downward trend in performance of the projects.

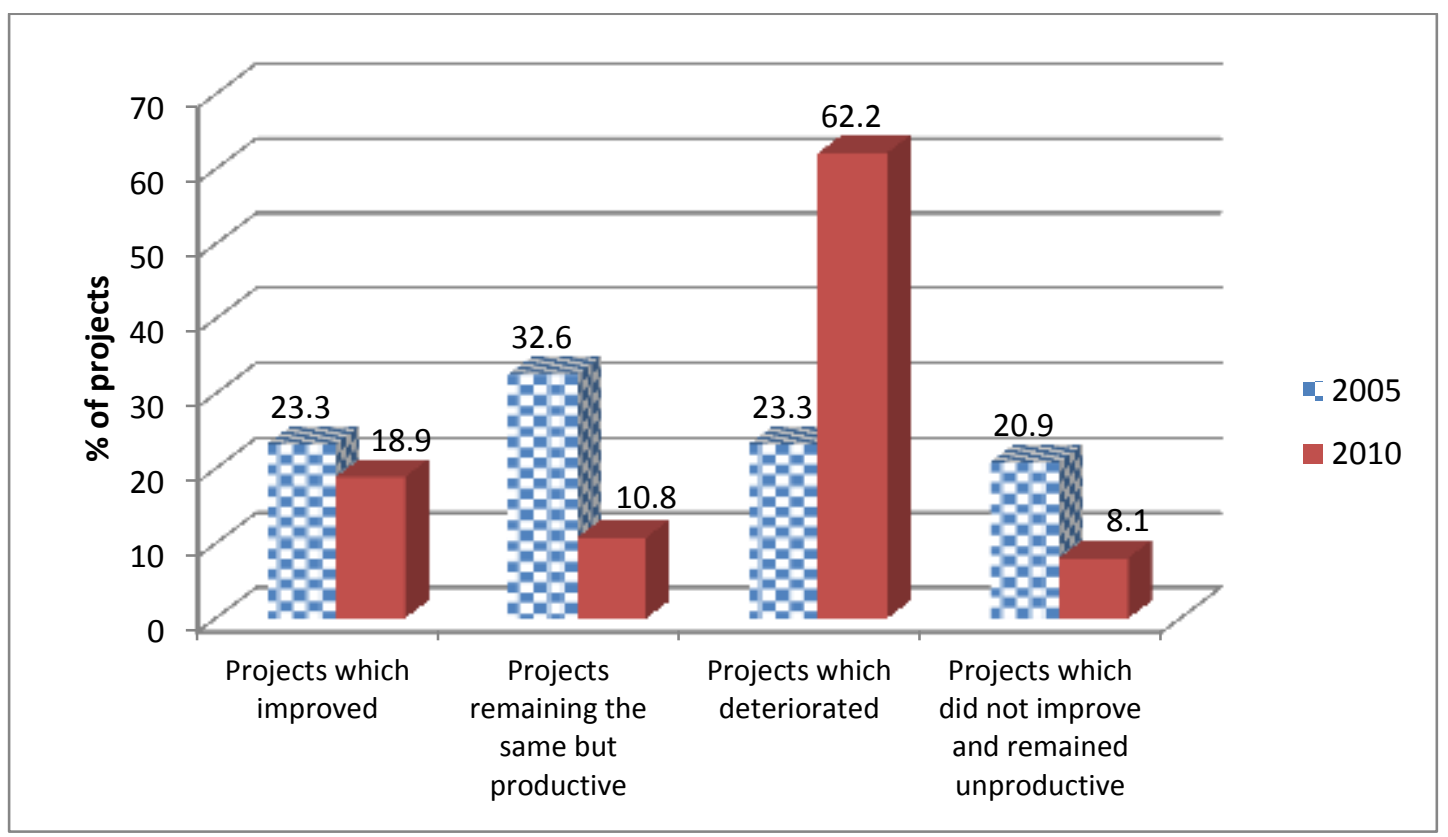

Figure 2: Performance trends in land reform projects in North West Province between 2005 and 2010

Overall, the projects that had previously experienced increasing or stable production failed to maintain or increase their levels of production since 2005. Of the ten projects with increasing production levels in 2005, none was still experiencing increased production in $2010^{3}$. About $22 \%$ of the projects had maintained the same levels of production, while in the rest of the projects, production levels were declining. There was, however, some improvement that is worth mentioning. Fifty per cent of the projects that had decreasing levels of production in 2005 had improved either to increasing or stable levels of production. On the other hand, $22.2 \%$ of the projects with no production at all in 2005 were experiencing increasing levels of production in 2010 . The beneficiaries

\footnotetext{
${ }^{3}$ Analysis excludes one 2005 Category 1 project which was not revisited in 2009.
} 
of these projects explained that there was no production in 2005 because they had only just started farming when the first survey was conducted and the production situation improved thereafter.

\section{Factors likely to influence agricultural performance on transferred farms}

Farming experience and the number of years since the transfer of the farm to the beneficiaries are considered to be important factors in determining the success of the farming operation. For this reason, the number of years since the farm was transferred when the 2005 survey was undertaken was investigated. For ten of the projects, the number of years since the farms were transferred ranged from four to six. Twenty-five projects were transferred seven to nine years before the visit in 2005 and two projects were transferred ten years or more before the visit. Therefore, there was sufficient start-up time for the projects and this ensured that the sample of projects is not biased towards recently transferred farms.

An attempt was also made to identify the occupation of beneficiaries before they acquired their land to determine the number of beneficiaries who were involved in farming before land reform, either as farm owners or as farm labourers. A significant proportion (48\%) of the respondents had been involved in some farming, either as farm owners or as farm labourers. Only $10 \%$ had farmed on a full-time basis and $28 \%$ of farm labourers were seasonal. Some (11\%) had been working for the government, while $16 \%$ of the 37 respondents had never worked before, $8 \%$ were pensioners and $3 \%$ were self-employed. It was assumed that, aside from training, beneficiaries who were farming before they acquired land stood a better chance of surviving than those who never farmed before. However, the results indicate a different scenario: $30 \%$ of beneficiaries who were involved in farming before are in Category 4 (no production) compared to the $21 \%$ with no farming background.

The proportion of active beneficiaries on a project provides an indication of the extent of beneficiary interest in the land reform projects. At the same time, the typical problem of free riding can result in conflict and unhappiness amongst group members, which can impact negatively on the general performance of the group in their farming venture. We have observed that not all members of the projects were active in farming activities. Our survey results reveal that only $20 \%$ of all the beneficiaries recorded were actively involved in farming. It was also evident that the more successful projects (Category 1) mostly have small groups and also a higher participation rate (58\% of group members). This supports the finding of our 2005 study that the production status of projects is positively related to the extent of the involvement of beneficiaries in farming activities.

Focus group discussions and detailed interviews with land reform beneficiaries, project officers and extension officer revealed the following as the main reasons for the deterioration or failure of some of the land reform projects in the North West Province:

i. Lack of access to funds to cover production costs and to invest in farm infrastructure. Funds provided by the state are inadequate and most beneficiaries are not willing to take the risks associated with borrowing from formal financial institutions. Without access to funds to purchase inputs or improve farm infrastructure, it is difficult to continue with production. 
ii. Poor market access. Beneficiaries have failed to secure reliable, low-cost markets or off-take agreements for their produce. This raises marketing costs, lowers profits and limits their potential to increase production.

iii. Internal conflicts within beneficiary groups over the sharing of benefits or the use of funds available for production. It is more difficult to manage disputes in larger groups. Conflicts are responsible for the deterioration of projects that were once in production.

iv. Low beneficiary interest because projects have not generated any immediate benefits and beneficiaries feel insecure about their ownership of the land.

v. Groups are too large, leading to conflict and a range of free-riding problems.

vi. Beneficiaries still lack technical and financial management skills to handle commercial farming needs. The limited and poor quality extension services and training provided to beneficiaries had no impact on the productive capacity of beneficiaries.

\section{Testing for the influence of group characteristics on the performance of land reform projects}

It is not clear from the above list of reasons for the deterioration or failure of some of the land reform projects as to which ones are the dominant. Based on the theory of collective action and the theory of groups (Olson, 1965) and the existence of free-riding problems, as well as efficiency in decision making in larger groups, it is often argued that aspects related to the composition of the beneficiary groups are the most important (factors iii, iv and v). Earlier studies on land reform projects in South Africa have shown that group and cooperative farming are a major cause of poor performance of land reform programmes (Binswanger-Mkhize, 2014). Unless they are small groups of family members or friends, there often are insurmountable problems with incentives for labour, management input, and for investment which lead to many conflicts, within communities, with strategic partners, and with government officials. Therefore, few of the Common Property Associations and Production Co-operatives are farming successfully (Binswanger-Mkhize, 2014).

Our survey amongst the land reform projects in North West Province found a number of examples of projects where group farming was a major problem. The question is, however, how significant this problem is and whether it is the dominant factor in shaping the performance of these farms. If it is not the case, then other aspects such as finance, access to markets and farming knowledge could be more important. Thus, the main purpose here is to test the influence of group dynamics on the performance of land reform projects. The two surveys of the panel of 37 land reform projects in North West Province provided an ideal opportunity to develop and test a set of propositions related to the influence of group attributes on the performance of the transferred farms.

\section{Proposition 1: Smaller groups (<5) are most successful}

On face value this seems to be true because the projects with five members or less had the greatest proportion (78\%) of projects in which production was either stable or increasing (Table 6). There is a steady decline in the proportion of successful projects as group size increases. In groups with 6-10 members, $50 \%$ of the projects are successful. The proportions of successful projects with groups of $11-20,21-50$ and more than 50 members were $44 \%, 38 \%$ and $33 \%$, respectively. 


\section{Proposition 2: All larger groups have failed}

This proposition is not supported because even though 9 of the 24 projects with more than ten members were not successful. The data show that there were 7 of the projects with larger groups that were successful by showing at least stable production. It is, therefore, clear that we cannot generalize and argue that all larger groups have failed. Those projects with groups with more than 20 members do however show limited success with 7 of the 11 projects being unsuccessful in 2005 .

Table 6: Performance of land reform projects (2005) by group size $(n=43)$

\begin{tabular}{|c|c|c|c|c|c|}
\hline \multirow[b]{2}{*}{ Group size } & \multicolumn{5}{|c|}{ Production status (2005) } \\
\hline & Category 1 & Category 2 & Category 3 & Category 4 & Total \\
\hline $1-5$ & 5 & 2 & 2 & 0 & 9 \\
\hline $6-10$ & 2 & 3 & 3 & 2 & 10 \\
\hline $11-20$ & 1 & 3 & 2 & 3 & 9 \\
\hline $21-50$ & 2 & 1 & 3 & 2 & 8 \\
\hline $51-100$ & 0 & 1 & 0 & 2 & 3 \\
\hline $101-200$ & 0 & 2 & 0 & 2 & 4 \\
\hline Total & 10 & 12 & 10 & 11 & 43 \\
\hline
\end{tabular}

Notes: Category 1: Projects showing increased production; Category 2: projects showing stable production; Category 3: projects showing decreased production; Category 4: projects showing no production

A Spearman correlation test was conducted to determine the relationship between a project's production status in 2010 and the number of members in each group. The results indicate that there is no significant relationship between the project's performance and the number of its members (Spearman rank coefficient $=0.196, n=36, p=0.253$ ). Hence, propositions 1 and 2 are rejected.

\section{Proposition 3: All small groups (<5) which were successful (operational) in 2005 will still be successful in 2010}

Table 7 shows the change in performance between 2005 and 2010 of seven small groups with less than five members each. The results indicate that five out of the seven groups (71.4\%) were worse off in terms of performance in 2010 than they were in 2005.

Table 7: Change in performance of small groups $(<5)$ from 2005 to 2010

\begin{tabular}{|l|c|c|c|c|}
\hline \multirow{2}{*}{$\begin{array}{l}\text { Number of } \\
\text { members in each }\end{array}$} & \multicolumn{2}{|c|}{ Change in production status from 2005 to 2010 } & Total \\
\cline { 2 - 5 } & Improved & Remained the same & Deteriorated & \\
\hline 1 & 0 & 0 & 2 & 2 \\
\hline 2 & 0 & 0 & 3 & 3 \\
\hline
\end{tabular}




\begin{tabular}{|l|l|l|l|l|}
\hline 4 & 1 & 1 & 0 & 2 \\
\hline Total & 1 & 1 & 5 & 7 \\
\hline
\end{tabular}

The Spearman correlation test indicates that there was a significant and negative relationship between the number of members and change in the projects' performance in 2010 (Spearman rank coefficient $=-0.825, n=7, p=0.022$ ). Thus, we can reject the proposition that all small groups that were successful in 2005 would maintain that level of success up to 2010.

\section{Proposition 4: Where conflict is present, production decreases}

Most internal group conflicts arise when beneficiaries have to either contribute towards production or share profits. Even though a constitution that stipulates the rules and regulations exists in these projects, in the absence of a clear management structure, good relations among members, the beneficiaries cannot resolve their own conflicts and thus often require the intervention of government officials. Conflicts also exist between groups of beneficiaries who share farm boundaries or farm infrastructure such as boreholes and electricity meters.

We now determine the level of association between the change in a projects' status and the presence or absence of conflict in 2005. A Cramer's V test $(0.308 ; p=0.331)$ indicates that there is a weak but insignificant relationship between the absence or presence of conflict in a group and the performance of 37 projects in 2010. A summary of the data presented in Table 8 indicates that the likelihood for failure is greater amongst groups where conflict is present since the production declined in $80 \%$ of the groups that experienced serious conflict in 2005 as opposed to $62 \%$ amongst groups where conflict was absent. The bottom-line is that the chances for failure are larger in groups with conflict - but that does not mean that all groups without conflict are successful.

Table 8: Performance of projects by presence or absence of conflict $(n=37)$

\begin{tabular}{|l|c|c|c|c|c|}
\hline \multirow{2}{*}{$\begin{array}{l}\text { Presence or absence of } \\
\text { serious problems/conflict }\end{array}$} & \multicolumn{4}{|c|}{ Change in production status from 2005 to 2010} & \multirow{2}{*}{} \\
\cline { 2 - 5 } & Improved & $\begin{array}{c}\text { Stable and } \\
\text { productive }\end{array}$ & Deteriorated & $\begin{array}{c}\text { Remained } \\
\text { unproductive }\end{array}$ & Total \\
\hline Present & $2(12.5 \%)$ & $1(6.5 \%)$ & $13(81 \%)$ & 0 & $\begin{array}{c}16 \\
(43.3 \%)\end{array}$ \\
\hline Absent & $5(23.8 \%)$ & $3(17.7 \%)$ & $11(52 \%)$ & $2(9.5 \%)$ & $\begin{array}{c}21 \\
(56.7 \%)\end{array}$ \\
\hline Total & 7 & 4 & 24 & 2 & 37 \\
\hline
\end{tabular}

(Cramer's V= 0.308, $n=36, p=0.331$ )

Source: own estimations based on 2005 survey data

\section{Proposition 5: Groups with conflict are too large}

The Cramer V statistic (0.416) indicates that there is a weak, but also insignificant, negative relationship between the size of a group and the presence of conflict, thus leading us to no statistical confirmation that we can expect larger groups will be more likely to have conflict, which is 
something that anecdotal evidence has shown to exist. Results in Table 9 indicate that conflict is highest (46.75\%) in groups with between 11 and 50 members.

Table 9: Problems or conflict in groups of different sizes $(n=37)$

\begin{tabular}{|l|c|c|c|c|c|c|c|}
\hline \multirow{2}{*}{$\begin{array}{l}\text { Existence of serious } \\
\text { problems or conflict amongst } \\
\text { members }\end{array}$} & \multicolumn{6}{|c|}{ Range of group sizes (number of members) } & \multirow{2}{*}{ Total } \\
\cline { 2 - 8 } & $1-5$ & $6-10$ & $11-20$ & $21-50$ & $51-100$ & $>100$ & 16 \\
\hline Yes & 1 & 3 & 3 & 5 & 2 & 2 & 21 \\
\hline No & 6 & 6 & 4 & 4 & 0 & 1 & 37 \\
\hline Total & 7 & 9 & 7 & 9 & 2 & 3 & 37 \\
\hline
\end{tabular}

(Cramer's $V=0.416, n=36, p=0.285$ )

Proposition 6: Groups with conflict are too large and too diverse

The results from Cramer V tests indicate a weak relationship (0.375) between the number of social ties that members have among themselves and the presence of conflict. Table 10 shows that nine out of fifteen $(60 \%)$ of the projects experiencing conflict shared only one or no form of tie amongst members. In the case of projects which did not experience any serious conflict or problems, $66.7 \%$ (15 out of the 22 projects) shared at least two types of ties amongst themselves - suggesting that a stronger social network is present.

Table 10: Number of ties shared in groups with and without conflict $(n=37)$

\begin{tabular}{|l|c|c|c|c|c|}
\hline \multirow{2}{*}{$\begin{array}{l}\text { Existence of serious } \\
\text { problems/conflict }\end{array}$} & \multicolumn{4}{|c|}{$\begin{array}{c}\text { Number of ties members shared before (family, friendship, } \\
\text { common residence, church, stokvel or any other) }\end{array}$} & \\
\cline { 2 - 5 } & 0 & 1 & 2 & 3 & \multirow{2}{*}{ Total } \\
\hline Yes (no. of projects) & 1 & 8 & 6 & 0 & 15 \\
\hline No (no. of projects) & 3 & 4 & 14 & 1 & 22 \\
\hline Total & 4 & 12 & 20 & 1 & 37 \\
\hline
\end{tabular}

(Cramer's V= 0.375, n=36, $\mathrm{p}=0.168$ )

Source: Estimation based on 2005 data

\section{Conclusion and policy recommendations}


Knowledge of how land reform projects are performing and the factors affecting the performance is vital if land reform is to achieve its intended objectives of equity, economic growth, rural development, and food security. Previous studies that have attempted to generate the knowledge have generally provided an incomplete picture due to their once-off nature and thus ignoring the fact that performance of land reform projects is not static.

In this paper, we have presented a detailed review of 37 land reform projects in the North West Province, covering the periods 2005 and 2010. Although we have relied on the production status of the projects in the two periods as an indicator of performance to the exclusion of other important indicators (due to lack of data or poor quality thereof), the paper provides a clear indication of how performance of the projects has changed during the 2005-2010 period. With a few exceptions, the agricultural performance of these projects has deteriorated during this period. The performance and progress are clearly varied but there is a significant deterioration in the production status of the projects in the province.

Although interviews with beneficiaries and government officials made it possible to identify what they considered to be the main reasons for the deterioration in performance of the projects, our analysis of data does not present a clear indication of significant causes of this steady decline in the productive ability of the redistributed farms. However, it is worth mentioning that our analysis was somewhat limited as it focused on the relationship between performance of the projects and group dynamics, particularly the notions of conflict, too many beneficiaries, and lack of beneficiary interest. We have applied a set of statistical tests to test these notions but none could be confirmed as significant. Therefore, it was difficult to conclude that group size and group conflict will always play an important role in the agricultural performance of transferred farms. It is clear that a combination of factors identified from interviews with beneficiaries and government officials have affected the performance of land reform projects in various ways. Some of the elements that came out the strongest were the delay in transfer of the land and limited post-transfer support. The weakest link in the land reform programme appears to be the neglect of resettled farmers once the transfer of land is complete. The state has a significant role to play in resolving this challenge.

We therefore recommend that the state pays more attention to improving access to post-transfer support services, including enhancing access to funds to cover start-up costs, training and extension services to ensure the long-term sustainable use of the land, and consequently maximise economic returns from production. These interventions could certainly go a long way in improving the agricultural performance of these projects and could even ensure that the harmony between group members is restored and interest in the farming activities also improved. Finally, future research is needed to analyse the performance of land reform projects in a more comprehensive manner in terms of both the indicators used and geographical coverage.

\section{Bibliography}

Agri Africa and Western Cape Department of Agriculture. 2005. Assessment of Agricultural Land Reform Projects in the Western Cape, November 2005

Besley, T. \& Burgess, R., 2000. Land Reform, Poverty Reduction and Growth: Evidence from India. Quarterly Journal of Economics, 115(2), pp. 389-430. 
Binswanger-Mkhize, H., 2014. From Failure to Success in South African Land Reform. Invited paper presented at the Annual conference of the Agricultural Economics Association of South Africa.

Mpekweni Beach Resort, September 30, 2014

Bradstock, A., 2005. Changing livelihoods and land reform:Evidence from the Northern Cape province of South Africa. World Development, 33(11), pp. 1979-1992.

Cliffe, L., 2000. Land reform in South Africa. Review of African Political Economy, 27(84), pp. 273-286.

Cousins, B. \& Scoones, I., 2010. Contested paradigms of 'viability' in redistributive land reform: perspectives from Southern Africa. The Journal of Peasant Studies, 37(1), pp. 31-66.

Deininger, K., 1999. Making negotiated land reform work: Initial experience from Colombia,Brazil and South Africa. World Development, 27(4), pp. 651-672.

Deininger, K., Hoogeveen, H. \& Kinsey, B., 2002. Benefits and Costs of Land Reform in Zimbabwe with Implications for Southern Africa. Understanding Poverty and Growth in Sub-Saharan Africa, 1819 March.

DLA 1997. White Paper on South African Land Policy. Department of Land Affairs, Pretoria Hall, R., Jacobs, P. \& Lahiff, E., 2003. Land Redistribution. Occasional Paper \#1 in Series: "Evaluating land and agrarian reform in South Africa. An Occassional Paper Series, PLAAS, University of Western Cape.

Hoogeveen, J. \& Kinsey, B., 2001. Land Reform, Growth and Equity:Emerging Evidence from Zimbabwe's Resettlement Programme-A Sequel. Journal of Southern African Studies, 27(1), pp. 127136.

HSRC 2003. Land Redistribution for Agricultural Development: Case Studies In Three Provinces. Integrated Rural and Regional Development, Human Sciences Research Council, Pretoria. October 2003.

Kirsten, JF and C. Machethe, 2005. Appraisal of Land Reform Projects in North-West Province. Unpublished review report to the National Department of Agriculture. University of Pretoria, Pretoria.

Lahiff, E. 2007. Land Redistribution in South Africa: Progress to date 1. Programme for Land and Agrarian Studies (PLAAS), University of the Western Cape, Paper presented at "Land

RedistributionTowards a Common Vision, Regional Course, Southern Africa.

Lahiff, E. 2008 Land Reform in South Africa: A Status Report 2008. Programme for Land and Agrarian Studies research report no. 38. School of Government, University of the Western Cape, Cape Town. July 2008.

Lahiff, E. \& Cousins, B., 2005. Smallholder Agriculture and Land reform in South Africa. IDS Bulletin, 36(2), pp.127-131

Lahiff, E., Davis, N. \& Manenzhe, T., 2012. Joint ventures in agriculture:Lessons from land reform projects in South Africa. International Institute for Environment and Development, London, UK. Lahiff, E. \& Li, L. 2012. Land Redistribution in South Africa: A Critical Review. Cape Town: PLAAS, University of the Western Cape.

Lubambo, P. , 2011. An appraisal of post-transfer production trends of selected land reform projects in the North West Province, South Africa. Unpublished M Inst Agrar mini-thesis, University of Pretoria, December 2011.

NDA 2004. Progress report on the implementation of the Comprehensive Agriculture Support Programme (CASP). Directorate Agricultural Production and Resource Management, National Department of Agriculture, Pretoria. May 2004. Available at http://www.nda.agric.za/docs/CASP/CASP\%20Report_31\%20August.pdf 
Olson, M. (1965). The Logic of Collective Action: Public Goods and the Theory of Groups. Harvard University Press, Cambridge, MA.

Place, F., 2009. Land Tenure and Agricultural Productivity in Africa: A comparative analysis of te Economics Literature and recent policy strategies and reforms. World Development, 37(8), pp. 13261336.

Public Service Commission (2011). A Meta-Evaluation of a Review of Land Redistribution for Agricultural Development (LRAD) Project Performance (2001-2006), Pretoria. Available at: http://www.psc.gov.za/documents/2011.

Rozelle, S. \& Swinnen, J. F., 2004. Success and Failure of Reform: Insights from the Transition of Agriculture. Journal of Economic Literature, 42(2), pp. 404-456.

Tilley, S. 2007. International Comparative Study of Strategies for Settlement Support Provision to Land Reform Beneficiaries. PLAAS Research Report 26, University of the Western Cape, Cape Town. Zimmerman, F. J., 2000. Barriers to participation of the poor in South Africa's Land Redistribution. World Development, 28(8), pp. 1439-1460. 